\title{
ISOLATION AND PURIFICATION OF BLASTICIDIN S DEAMINASE FROM ASPERGILLUS TERREUS
}

\author{
Isamu Yamaguchi, Hiroko Shibata, Haruo Seto* and Tomomasa Misato \\ The Institute of Physical and Chemical Research, \\ Wako-shi, Saitama Pref., Japan \\ *Institute of Applied Microbiology, University of Tokyo, Tokyo \\ (Received for publication September 6, 1974)
}

\begin{abstract}
An enzyme catalyzing the deamination of the cytosine moiety of blasticidin S was extracted from a fungal strain that belongs to Aspergillus terreus. The enzyme was purified with ammonium sulfate fractionation, Sephadex G-100 column and DEAE cellulose column chromatography, followed by preparative polyacrylamide gel electrophoresis. Blasticidin S deaminase could be separated easily from co-existing cytidine deaminase by DEAE column chromatography or gel electrophoresis, and preliminary study on the substrate specificity showed that this enzyme acts on blasticidin $\mathrm{S}$ derivatives, such as cytomycin and acetylblasticidin S, but not on cytosine, cytidine, purine bases or their nucleosides. Blasticidin $\mathrm{S}$ deaminase could be induced by the addition of blasticidin $\mathrm{S}$ to the culture, and sulfhydryl compounds, such as mercaptoethanol, were effective in protecting the enzyme from inactivation. The homogeneity of the enzyme was examined by both sedimentation analysis and polyacrylamide gel electrophoresis. The molecular weight and isoelectric point were found to be around 30,000 and 4.35 , respectively. Some other properties were also examined.
\end{abstract}

In the course of an investigation on the fate of blasticidin $\mathrm{S},{ }^{1)}$ an agricultural antibiotic, in the environment, we found that a fungal strain, isolated from a soil of paddy field, was able to decrease significantly the bioactivity of the antibiotic. ${ }^{2)}$

The structure of blasticidin $\mathrm{S}$ was determined by ŌTAKE et al. ${ }^{3}$; it consists of cytosinine, a new nucleoside, and a $\beta$-amino acid designated as blastidic acid. As previously reported, ${ }^{2)}$ the enzymatic deamination product of blasticidin $\mathrm{S}$ was identified as deaminohydroxyblasticidin $\mathrm{S}^{4)}$ by TLC and UV spectra; it differs from blasticidin $\mathrm{S}$ in the pyrimidine base, i.e., uracil instead of cytosine (Fig. 1).

Many enzymes are known which deaminate purine or pyrimidine compounds, and the deamination of cytosine and its derivatives has been observed in various tissues and microorganisms. ${ }^{5,8)} \quad$ Blasticidin $\mathrm{S}$ deaminase (blasticidin $\mathrm{S}-$ cytosine aminohydrolase) is also Fig. 1. Enzymatic transformation of blasticidin S.<smiles>[R]c1ccn(C2C=CC(NC(=O)CC(N)CCN(C)C(=N)N)C(C(=O)O)O2)c(=O)n1</smiles>

Blasticidin $\mathrm{S}: \mathrm{R}=\mathrm{NH}_{2}$ Deaminohydroxyblasticidin $\mathrm{S}: \mathrm{R}=\mathrm{OH}$ considered a deaminase of cytosine derivatives.

In this paper, the purification and some properties of blasticidin $\mathrm{S}$ deaminase from Aspergillus terreus are described.

\section{Materials and Methods}

Identification of fungus: Colonies on CZAPEK-Dox's solution agar grow rather rapidly, reaching a diameter of $3.4 \sim 4.0 \mathrm{~cm}$ in 10 days at $25 \sim 26^{\circ} \mathrm{C}$; they have shallow radial furrows, velvety, becoming floccose, with margins usually thin and irregular; heavy sporing is observed 
throughout, with massed columnar heads giving the colonies their characteristic texture and color ranging from pale yellow to pale brown; abundant pale amber exudate is produced; odor is absent; the reverse is dark yellow orange to dark orange. Conidial heads are long, columnar, compact, of uniform diameter throughout their length, commonly ranging from 30 to $50 \mu$ in diameter and $150 \sim 500 \mu$ or more in length in about 15 days. Conidiospores are more or less flexuous, smooth, colorless, commonly $170 \sim 200 \mu$ in length and $4.5 \sim 5.0 \mu$ in diameter, approximately uniform in diameter throughout; vesicles are hemispherical, dome-like, commonly $10 \sim 16 \mu$ in diameter; sterigmata are in two series: the primary sterigmata are crowded, parallel, $5.0 \sim 6.0 \mu$ by $2.0 \sim 2.5 \mu$; the secondary sterigmata are closely packed, $5.5 \sim 6.0 \mu$ by 1.5 $\sim 2.0 \mu$; conidia are globose to slightly elliptical, smooth, commonly $1.5 \sim 2.0 \mu$ in diameter.

Colonies on malt extract agar grow rapidly, attaining a diameter of $6.0 \sim 6.4 \mathrm{~cm}$ in 10 days at $25 \sim 26^{\circ} \mathrm{C}$; they are thin plane, heavily sporulating throughout; the conidial heads are in shade of pale brown; the reverse is in pale yellowish brown shades.

From the characters described above and by comparison with an authentic strain, the fungus was identified as Aspergillus terreus.

Preparation of crude enzyme extract: Spores of $A$. terreus on a yeast-starch slant $(0.5 \%$ yeast extract, $2.0 \%$ soluble starch and $1.5 \%$ agar) were inoculated in to a yeast-glucose medium $(0.5 \%$ yeast extract and $2 \%$ glucose, $\mathrm{pH} 7.0)$ containing blasticidin $\mathrm{S}(1 \mathrm{mg} / \mathrm{ml})$ and incubated at $28^{\circ} \mathrm{C}$ for 40 hours, unless otherwise stated. A portion of the pre-cultured mycelia was transferred to a fresh medium, free of blasticidin $\mathrm{S}$, and cultured at $28^{\circ} \mathrm{C}$ on a reciprocal shaker for about 50 hours. The cultured mycelia were collected by filtration, and washed twice with distilled water and once with $0.015 \mathrm{M}$ phosphate buffer (pH 6.5).

The washed mycelia (1 volume) were ice-cooled, suspended in cold phosphate buffer (2 volumes), homogenized in a Waring blendor, and disrupted by passage through a French pressure cell $\left(1,000 \mathrm{~kg} / \mathrm{cm}^{2}\right)$ or by two treatments in a Manton Gaulin homogenizer $\left(300 \mathrm{~kg} / \mathrm{cm}^{2}\right)$.

Enzyme assay: A spectrophotometric assay, based on the differential absorption of the substrate and product, was generally used. ${ }^{5)}$ The reaction mixture contained, in a final volume of $250 \mu \mathrm{l}, 0.01 \mathrm{M}$ Tris- $\mathrm{HCl}$ buffer ( $\mathrm{pH} 7.5$ ), various amounts of enzyme preparation and substrate; the reactions were carried out at $30^{\circ} \mathrm{C}$ for various periods of time, and terminated by the addition of $4.75 \mathrm{ml}$ of $0.1 \mathrm{~N} \mathrm{HCl}$. The decrease in optical density at $282 \mathrm{~nm}$ was measured against a reference in which the enzyme preparation was replaced by the buffer. Sometimes the bioassay was performed in parallel with the spectrophotometric assay; the enzyme reaction was stopped by dipping the reaction mixture in boiling water for 5 minutes; then the residual antibiotic activity was determined by the disc plate method using Bacillus cereus as the test organism.

Protein was determined by the method of LOwRY et al., ${ }^{7)}$ using crystalline bovine serum albumin as a standard, or by the absorbance method $\left(\mathrm{OD}_{280}\right)$.

Enzyme purification: All the procedures were conducted at $4^{\circ} \mathrm{C}$ or below. The crude enzyme extract was centrifuged at $1,500 \mathrm{~g}$ for 15 minutes, and the supernatant was again centrifuged at $15,000 \mathrm{~g}$ for 20 minutes. To this supernatant, designated as S-15 fraction, solid ammonium sulfate was added gradually to achieve $25 \%(\mathrm{w} / \mathrm{v})$ and the precipitate was removed by centrifugation; a second precipitate was obtained by further addition of ammonium sulfate,

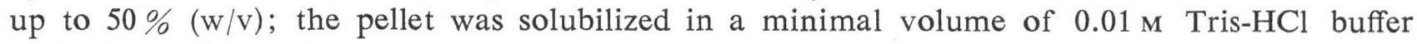
(pH 7.5). This fraction was applied to a Sephadex G-100 column, and developed with Tris$\mathrm{HCl}$ buffer containing $5 \mathrm{~mm}$ mercaptoethanol. In this procedure, the enzyme protein was separated from most of the foreign proteins and residual ammonium sulfate. Active fractions were combined and concentrated, if necessary, by vacuum ultrafiltration through a collodion bag, then adsorbed on a DEAE cellulose column equilibrated with the buffer described above, and fractionated by elution with linear $\mathrm{NaCl}$ gradient up to $0.5 \mathrm{M}$. Enzyme fractions were pooled, concentrated by ultrafiltration and are referred to as the DEAE cellulose fraction. Subsequent steps in the purification procedure were carried out by polyacrylamide gel electro- 
phoresis. The DEAE cellulose fraction was dialyzed, the dialyzate applied with sucrose $(20 \%$ $\mathrm{w} / \mathrm{v}$ ) on a stacking gel, and a constant current of $50 \mathrm{~mA}$ applied, using a Toyo CD-50 preparative polyacrylamide gel electrophoresis apparatus. Tris-glycine buffer ( $\mathrm{pH} \mathrm{8.4)}$ was used for the first electrophoresis, then active fractions were combined and concentrated as described above; the second electrophoresis was performed with Tris-barbital buffer ( $\mathrm{pH}$ 7.0). Enzyme fractions were again pooled and concentrated in a collodion bag, and then dialyzed overnight against $0.01 \mathrm{M}$ Tris- $\mathrm{HCl}$ buffer ( $\mathrm{pH} 7.5)$. The purified enzyme preparation was usually stored at $-20^{\circ} \mathrm{C}$ in $50 \%$ glycerin in the presence of $5 \mathrm{~mm}$ mercaptoethanol. No appreciable loss of the activity was observed in the preparation after 3 months of storage.

Homogeneity of the enzyme: The purified enzyme in $0.01 \mathrm{~m}$ Tris- $\mathrm{HCl}$ buffer containing $0.1 \mathrm{M} \mathrm{NaCl}$ was applied to sedimentation analysis employing a Hitachi UCA-1 analytical ultracentrifuge equipped with a synthetic boundary cell and an RA-60 rotor. The rotor speed was $55,430 \mathrm{rev} . / \mathrm{min}$. Homogeneity of the enzyme was also examined by disc-gel electrophoresis according to the method of DAvis et al. ${ }^{8)}$ The electrophoresis was carried out at $4^{\circ} \mathrm{C}$ for 50 minutes at $3 \mathrm{~mA} /$ tube and protein bands were stained by amideblack $10 \mathrm{~B}$.

Molecular weight and isoelectric point: The molecular weight was determined by ultracentrifugation according to the ARCHIBALD method ${ }^{9)}$ and by SDS polyacrylamide gel electrophoresis. ${ }^{10)}$

The isoelectric focusing technique ${ }^{11)}$ was used to examine the isoelectric point of the enzyme. The purified enzyme protein was dialyzed against $1 \%$ glycine overnight at $4^{\circ} \mathrm{C}$ before charging into an electrofocusing apparatus equipped with an LKB 8100 column. Ampholine carrier ampholites, $\mathrm{pH} 3$ to 10 , in sucrose density gradient were used, and focusing was carried out at a constant potential of $300 \mathrm{~V}$ for 50 hours. Each 2 -ml portion was pumped out of the column, and enzyme activity was measured at around $\mathrm{pH} 7.15$.

Substrates and reagents: Blasticidin S hydrochloride and free base were kindly supplied by Kaken Chemical Co., Ltd., Tokyo. Pyrimidine or purine bases and their nucleosides were obtained either from Sigma Chemical Co. or Seikagaku Kogyo Co., Tokyo. Sephadex G-100, G-200 and blue dextran 2000 were purchased from Pharmacia Fine Chemicals and protein markers were obtained from $M$ \& $S$ Instruments Inc. DEAE cellulose and reagents for gel electrophoresis were purchased from Seikagaku Kogyo Co. Other chemicals were of reagent grade or of the highest quality available.

\section{Results}

Aspergillus terreus produced far more enzyme when grown in the presence than in the absence of blasticidin $S$ in the culture medium; growth was not much affected by the antibiotic, as shown in Fig. 2. Such inducing effect was also obtained with gougerotin, a similar aminohexose pyrimidine nucleoside antibiotic, but not with other

Fig. 2. Effect of blasticidin $\mathrm{S}$ on mycelial growth and $\mathrm{Bc} \mathrm{S}$ deaminase production of $A$. terreus. $A$. terreus was grown in the presence $(1,000$ $\mu \mathrm{g} / \mathrm{ml}$ ) or absence of blasticidin $\mathrm{S}$ in yeastglucose medium (A).

Enzyme activity of each S-15 fraction was examined and calculated from $-\Delta \mathrm{OD}_{282}$; one unit is that amount of enzyme which deaminates one micromole of substrate per minute (B).

Presence of blasticidin S: (1) in the preculture medium, (2) in the culture medium, (3) in both media and (4) no blasticidin S.

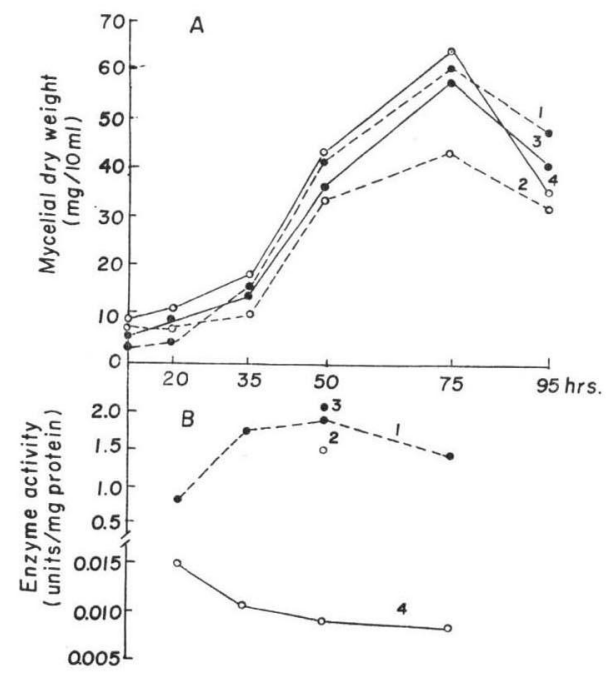


antibiotics, such as streptomycin, polyoxins, antimycin A or aabomycin, or with antimicrobial substances, such as bromouracil or phenylmercuriacetate. Neither cytosine, cytidine, nor cytosinine and cytomycin, which are derivatives of blasticidin S, gave rise to enzyme induction. The effect of the addition of blasticidin $\mathrm{S}$ was also observed in subcultures grown in a fresh medium free of the inducer.

The elution profile of blasticidin $\mathrm{S}$ deaminase (abbreviated $\mathrm{Bc} \mathrm{S}$ deaminase) from a DEAE cellulose column is shown in Fig. 3. The enzyme was eluted at a concentration of $c a .0 .3 \mathrm{M}$ sodium chloride, and clearly separated from cytidine deaminase. Though most of the inactive proteins were removed, the purification factor at this step was not so high unless the eluting buffer contained mercaptoethanol; this suggests some inactivation to have occurred.

The protein content, specific activity and recovery of the enzyme at each stage of a typical purification run are summarized in Table 1. An overall 200-fold purification was achieved, and the recovery of enzymic activity was $14 \%$.

The homogeneity of the purified Bc S deaminase was examined by disc-gel electrophoresis

Fig. 3. Elution profile of $\mathrm{Bc} \mathrm{S}$ deaminase and cytidine deaminase on DEAE cellulose column chromatography.

Column size, $2.1 \times 45 \mathrm{~cm}$; flow rate, $24 \mathrm{ml} / \mathrm{hr}$. The column was equilibrated and eluted with $0.01 \mathrm{M}$ Tris- $\mathrm{HCl}$ buffer ( $\mathrm{pH} 7.5$ ) containing $5 \mathrm{~mm}$ mercaptoethanol.

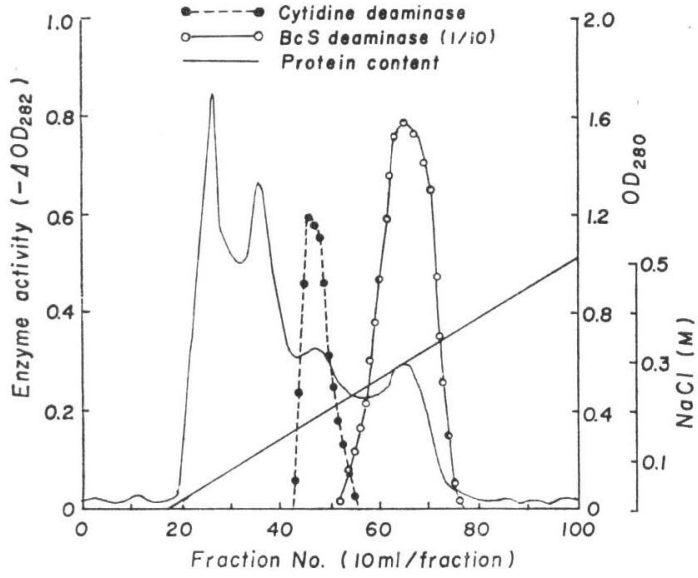
and sedimentation analysis. A single band of protein, which corresponds to the active band, was observed when the enzyme was subjected to analytical disc electrophoresis in $\mathrm{pH} 9.4,{ }^{8)}$

Fig. 4. Polyacrylamide gel electrophoretograms of $\mathrm{Bc} \mathrm{S}$ deaminase.

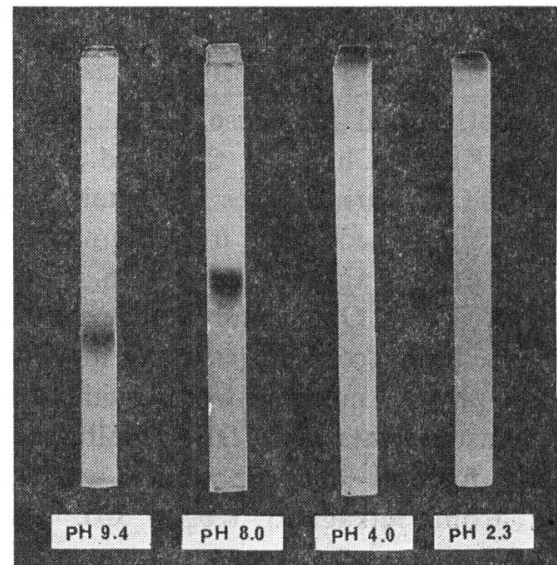

Table 1. Purification of Bc $\mathrm{S}$ deaminase from A.terreus.*

\begin{tabular}{l|c|c|c}
\hline \multicolumn{1}{c|}{ Fraction } & $\begin{array}{c}\text { Protein } \\
(\mathrm{mg})\end{array}$ & $\begin{array}{c}\text { Specific activity } \\
\text { (units/mg protein) }\end{array}$ & $\begin{array}{c}\text { Total activity } \\
\text { (units) }\end{array}$ \\
\cline { 2 - 3 } Crude extract & 13,200 & 1.10 & 14,500 \\
S-15 & 5,200 & 1.85 & 9,620 \\
Ammonium sulfate & 2,200 & 3.10 & 6,820 \\
Sephadex G-100 & 515 & 7.20 & 3,710 \\
DEAE cellulose & 74.5 & 39.50 & 2,940 \\
Preparation I** & 21.0 & 106.00 & 2,230 \\
Preparation II** & 9.0 & 220.50 & 1,980 \\
\hline
\end{tabular}

* The procedures were described under Materials and Methods.

** Preparations by the first and second polyacrylamide gel electrophoresis. 
$8.0,{ }^{12)} 4.0,{ }^{13)}$ and 2.3 gels, as shown in Fig. 4. The enzyme moved quickly at high $\mathrm{pH}$ but not under acidic conditions. The homogeneity of the enzyme was also investigated by sedimentation velocity experiments using an analytical ultracentrifuge; a single symmetrical sedimentation boundary corresponding to $S_{20, w}$ value of 2.98 was observed (Fig. 5).

Fig. 5. Ultracentrifugal sedimentation patterns of $\mathrm{Bc} \mathrm{S}$ deaminase.

The concentration of the enzyme protein was $0.52 \%$ in $0.01 \mathrm{M}$ Tris- $\mathrm{HCl}$ buffer ( $\mathrm{pH} 7.5$ ) containing $0.1 \mathrm{M} \mathrm{NaCl}$ and $1.0 \mathrm{~mm}$ mercaptoethanol. The temperature was $25^{\circ} \mathrm{C}$. The photographs were taken at the indicated times after reaching 55,430 rev./min. The direction of sedimentation was toward right.

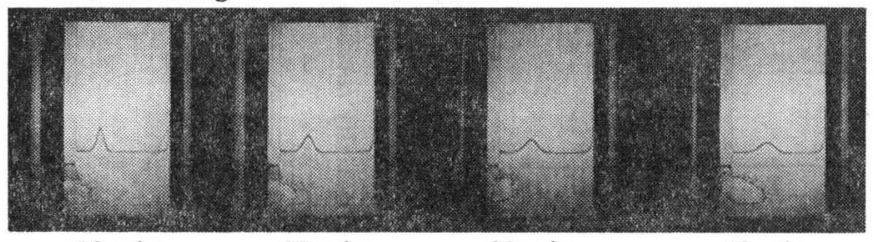

$$
10 \mathrm{~min} . \quad 20 \mathrm{~min} . \quad 30 \mathrm{~min} . \quad 40 \mathrm{~min} .
$$

The molecular weight of the enzyme estimated from the sedimentation analysis by the Archibald method ${ }^{9)}$ was approximately 29,600 on the assumption that $1-v \rho$ is 0.2523 . This value is in good agreement with that obtained by SDS polyacrylamide gel electrophoresis by the method of Weber et al. ${ }^{10)}$ Gel filtration on a Sephadex G-200 column, however, did not afford coincidence with the value described above (see discussion). A mixture of enzyme preparation and marker proteins of known molecular weights was applied to a column $(2.5 \times$ $72 \mathrm{~cm}$ ), equilibrated with $0.01 \mathrm{M}$ Tris- $\mathrm{HCl}$ buffer $(\mathrm{pH} 7.5)$ containing $0.1 \mathrm{M} \mathrm{NaCl}$, and then eluted with the same buffer, at a flow rate of $7 \mathrm{ml} /$ hour. The apparent molecular weight of the enzyme was estimated to be 46,000 . The elution volume corresponding to $\mathrm{Bc} \mathrm{S}$ deaminase varied significantly depending on the presence or absence of $\mathrm{NaCl}$; if sodium chloride was omitted from the buffer, the molecular weight was estimated to be 55,000 (Fig. 6).

The isoelectric point of the enzyme was estimated according to the electrofocusing method described in Materials and Methods, and the value obtained was approximately 4.35 (Fig. 7). Therefore this enzyme is charged with anion, and this finding coincides with the

Fig. 7. Isoelectric focusing pattern of $\mathrm{Bc} \mathrm{S}$ deaminase.

Gradient of $\mathrm{pH}$ and enzyme activity under $\mathrm{pH}$ conditions of assay were measured according to Materials and Methods.

Fig. 6. Effect of ionic strength on the elution profile of $\mathrm{Bc} \mathrm{S}$ deaminase from a Sephadex G-200 column.
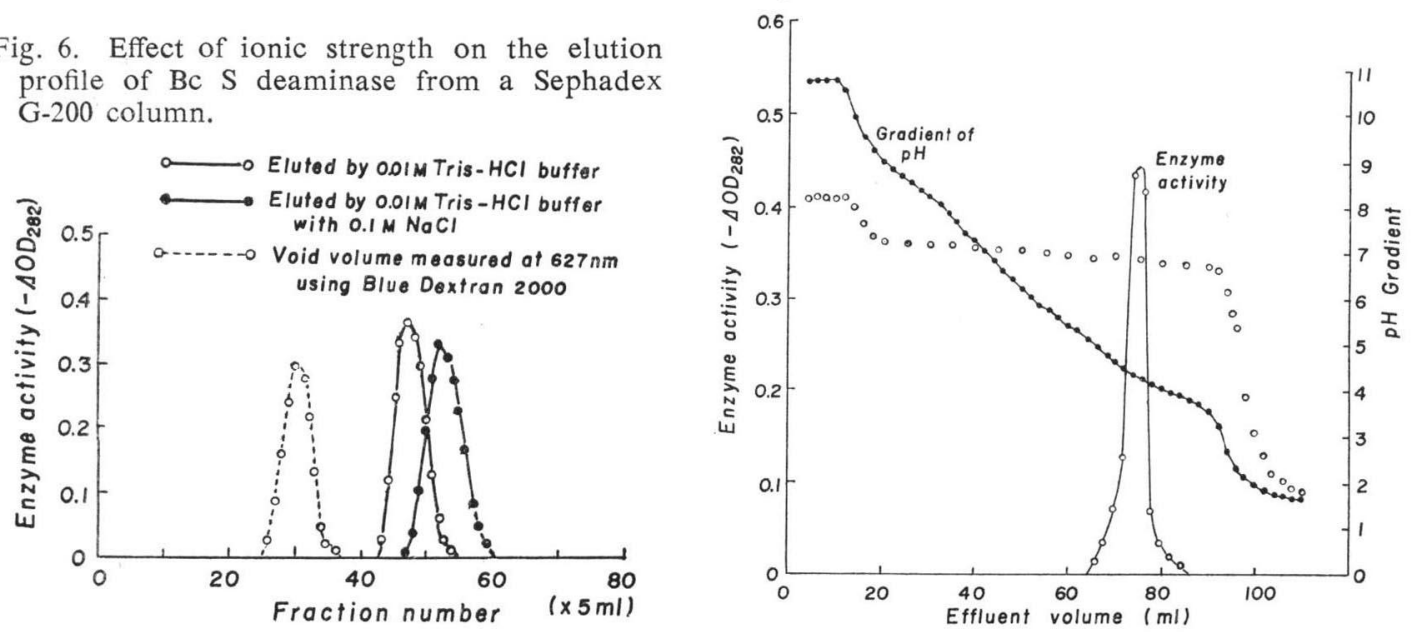
Fig. 8. Effect of $\mathrm{pH}$ on $\mathrm{Bc} \mathrm{S}$ deaminase activity. Buffers used: (1) formate, (2) acetate, (3) cacodylate, (4) phosphate, (5) Tris- $\mathrm{HCl}$, (6) glycinate, (7) bicarbonate.

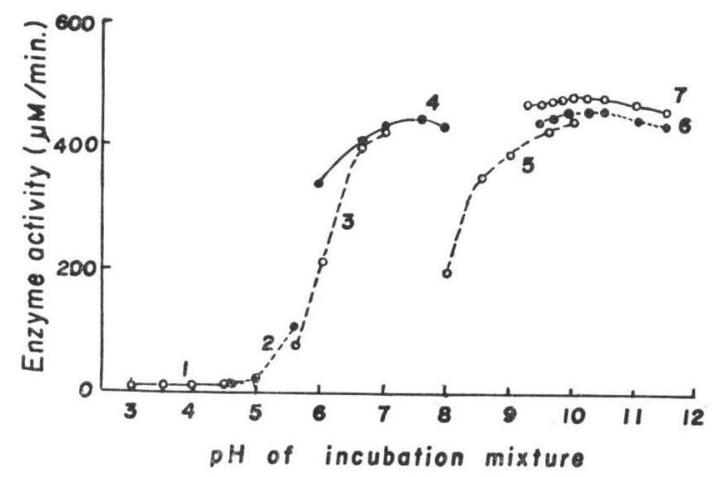

results obtained by disc gel electrophoresis.

The effect of incubation temperature on enzyme reaction was examined. The reaction was conducted at 20, 25, 30, 35, 40, 50, 60, 70 and $80^{\circ} \mathrm{C}$. The reaction proceeded most rapidly at $60 \sim 70^{\circ} \mathrm{C}$, and it occurred only during a short initial period at $80^{\circ} \mathrm{C}$.

Fig. 8 shows the reaction rate as a function of the hydrogen ion concentration. The mixture contained $25 \mu \mathrm{l}$ of enzyme preparation $(10 \mu \mathrm{g} / \mathrm{ml}), 25 \mu \mathrm{l}$ of $10 \mathrm{~mm}$ blasticidin $\mathrm{S}$ and $200 \mu$ of each buffer. Buffers at constant ionic strength of $0.05 \mu$ were used. The pH optimum was found to be near 10. At $\mathrm{pH}$ values lower than 4.5, rapid inactivation of the enzyme occurred.

Heat sensitivity of $\mathrm{Bc} \mathrm{S}$ deaminase was tested in Tris- $\mathrm{HCl}$ buffer and the results are shown in Fig. 9. The enzyme was partially protected from thermal inactivation by the presence of bovine serum albumin of mercaptoethanol.

$\mathrm{Bc} \mathrm{S}$ deaminase from $A$. terreus is highly sensitive to sulfhydryl inhibitors, such as mercurial

Table 2. Inhibition and reactivation of $\mathrm{Bc} \mathrm{S}$ deaminase.

\begin{tabular}{|c|c|c|c|c|}
\hline \multirow{2}{*}{$\begin{array}{l}\text { SH inhibitor } \\
(\mathrm{mm})\end{array}$} & \multicolumn{4}{|c|}{ SH protective reagent $(20 \mathrm{~mm})$} \\
\hline & None & GSH & ME & DTT \\
\hline None & $100.0 \%$ & $99.5 \%$ & $100.0 \%$ & $99.7 \%$ \\
\hline$p \mathrm{CMB} \quad(0.01)$ & 25.5 & 75.2 & 97.8 & 91.0 \\
\hline$(0.1)$ & 0.0 & 58.3 & 58.3 & 59.3 \\
\hline $\mathrm{HgCl}_{2} \quad(0.01)$ & 0.0 & 75.2 & 95.4 & 91.0 \\
\hline$(0.1)$ & 0.0 & 69.2 & 91.0 & 81.3 \\
\hline $\mathrm{CuCl}_{2} \quad(0.1)$ & 32.8 & 70.4 & 93.4 & 80.0 \\
\hline$(1.0)$ & 0.0 & 20.6 & 37.6 & 47.3 \\
\hline NEM $\quad(1.0)$ & 97.1 & - & - & - \\
\hline$(10.0)$ & 75.2 & - & - & - \\
\hline MIA $\quad(1.0)$ & 96.9 & - & - & - \\
\hline$(10.0)$ & 81.3 & - & - & - \\
\hline
\end{tabular}

Fig. 9. Effect of mercaptoethanol and bovine deaminase. for given periods, rapidly chilled, and remaining activity was assayed with $250 \mathrm{~m} \mu \mathrm{M}$ blasticialbumin (BSA).

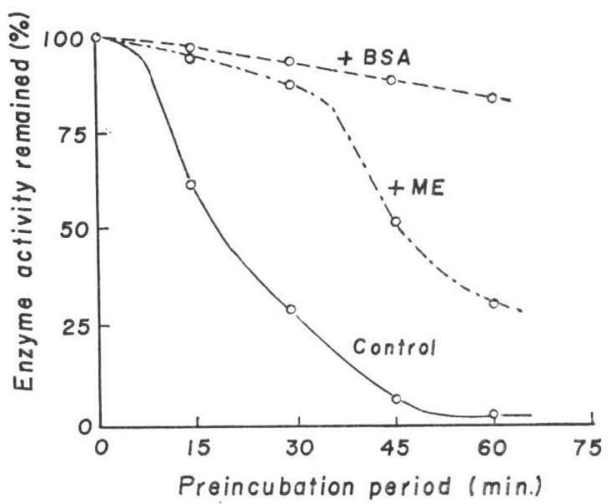
serum albumin on thermal inactivation of $\mathrm{Bc}$ mercaptoethanol (ME) or 1 mut bovine serum 
ion, $p$-chloromercuribenzoate ( $p \mathrm{CMB}$ ) or cupric ion, but fairly resistant to $\mathrm{N}$-ethylmaleimide (NEM) or monoiodoacetate (MIA); the activity could be recovered by the addition of sulfhydryl compounds, e.g. glutathione (GSH), mercaptoethanol (ME) or dithiothreitol (DTT) as shown in Table 2.

A preliminary study of substrate specificity was also conducted. The reaction mixture contained, in a final volume of $500 \mu \mathrm{l}$, different amounts of the enzyme and $250 \mathrm{~m} \mu \mathrm{M}$ of substrate in $0.01 \mathrm{M}$ Tris- $\mathrm{HCl}$ buffer $(\mathrm{pH} 7.5)$. The rate of deamination of each substrate was followed by spectrophotometric assay with a Shimazu UV 200 absorbance recording spectrophotometer. Besides blasticidin S, monoacetylblasticidin $\mathrm{S}^{*}$ and cytomycin were good substrates for the enzyme, while gougerotin, cytidine or deoxycytidine were only slightly deaminated even at higher concentrations of the enzyme. In contradistinction, cytosinine, cytosine, CMP, d-CMP, adenine, adenosine, AMP, guanine, guanosine and GMP were not deaminated. Details of the substrate specificity and reaction kinetics will be reported elsewhere.

\section{Discussion}

The data presented indicate the presence in Aspergillus terreus of an enzyme capable of deaminating blasticidin $\mathrm{S}$, an aminohexose pyrimidine nucleoside antibiotic. Blasticidin $\mathrm{S}$ deaminase, which is considered to be a nucleoside aminohydrolase, is found to exist in several other microorganisms, especially in several species of the genus Aspergillus: A. flavipes NHL 5013, A. fumigatus NHL 5009, A. terreus NHL 5037, A. flavus ATCC 9643, A. ochraceus 67-MI87 and $A$. ustus 1004.

The enzyme in $A$. terreus was induced by blasticidin $\mathrm{S}$ and also by gougerotin, a similar pyrimidine nucleoside antibiotic, which was only slightly deaminated by the enzyme. In contradistinction, cytomycin, which is a non-antimicrobial derivative of blasticidin $\mathrm{S}$ and a good substrate for the enzyme, did not induce the enzyme. It has often been recognized that substances other than the normal enzyme substrate may act as enzyme inducers in microorganisms, and it appears that the specificity of enzyme induction is related to, but distinct from, the specificity of enzyme function. While many studies on the induction of penicillinase, ${ }^{14,15)}$ on microorganisms carrying $\mathrm{R}$-factor resistance to chloramphenicol, streptomycin, kanamycin etc. ${ }^{16)}$ and on the regulatory mechanism of protein synthesis ${ }^{17)}$ have been reported, a satisfactory interpretation of resistance and related enzyme induction in fungi has not yet been provided. In this connection, the mechanism of synthesis of $\mathrm{Bc} \mathrm{S}$ deaminase and its function in the organism is worth investigating. Other experiments indicated that a resistant clone of Pyricularia oryzae, which was obtained by selection with blasticidin S, could not deaminate the antibiotic (YAMAGUCHI, I.: Unpublished data).

Though $\mathrm{Bc} \mathrm{S}$ deaminase resembles cytidine deaminase in many respects, e.g., behavior on Sephadex gels, and sensitivity to mercurial agents and others, ${ }^{6)}$ the enzyme is well separated from cytidine deaminase by DEAE cellulose chromatography and substrate specificity, which will be reported in detail in the following paper; this may imply that the enzyme is a new aminohydrolase acting on specific nucleosides.

The molecular weight of $\mathrm{Bc} \mathrm{S}$ deaminase was estimated to be $c a .30,000$ by sedimentation analysis and SDS polyacrylamide gel electrophoresis, while the results of gel filtration on a Sephadex G-200 column were not in agreement with the value described above. Preliminary experiments suggest that the anomalous gel filtration behavior of $\mathrm{Bc} \mathrm{S}$ deaminase may be attributed to the presence of carbohydrates in the enzyme molecules, as reported by ANDREws. ${ }^{18)}$ Moreover, the elution profile of Bc S deaminase on Sephadex gel is much more influenced by ionic strength than marker proteins of known molecular weight, and this may indicate that

* Seto, H.: To be published. 
higher ionic strength causes considerable conformational changes of the enzyme molecules and/or the decrease of ionic interaction of enzyme molecules and the acidic groups of Sephadex gels. The possibility that the enzyme may dissociate into subunits under conditions of higher ionic strength was ruled out, since the apparent molecular weight of $\mathrm{Bc} \mathrm{S}$ deaminase, which was estimated at 46,000 from the elution volume in the presence of $0.1 \mathrm{M} \mathrm{NaCl}$, increased to 55,000 when rechromatographed in the absence of $\mathrm{NaCl}$ (lower ionic strength).

\section{Acknowledgement}

The authors wish to thank Dr. H. Kurata of the National Institute of Hygienic Sciences for co-operation in the identification of the fungus, and Mr. M. Chismatsu for ultracentrifugal data. We are grateful to Drs. S. TAKeuchi, T. Ando and H. Horikoshi of the Institute of Physical and Chemical Research, and to Dr. H. Yonehara of the Institute of Applied Microbiology, University of Tokyo, for their continued interest and encouragement throughout our work.

\section{References}

1) Takeuchi, S.; K. Hirayama, K. Ueda \& H. Yonehara: Blasticidin S, a new antibiotic. J. Antibiotics, Ser. A 11: 1 5, 1958

2) Yamaguchi, I.; K. TAKagi \& T. Misato: The fate of blasticidin S, an agricultural antibiotic, in the environment. I. The site for degradation of blasticidin S. Agr. Biol. Chem. 36: 1719 1727,1972

3) Ōtake, N.; S. Takeuchi, T. Endo \& H. Yonehara: Chemical studies on blasticidin S. III. The structure of blasticidin S. Agr. Biol. Chem. 30: 132 141, 1966

4) Seto, H.; N. Ōtake \& H. Yonehara: Biological transformation of blasticidin $\mathrm{S}$ by Aspergillus fumigatus sp. I. Isolation, characterization and structure of transformed products and their biological properties. Agr. Biol. Chem. 30: 877 886, 1966

5) Wang, T. P.; H. Z. Sable \& J. O. LAmpen: Enzymatic deamination of cytosine nucleosides. J. Biol. Chem. 184: 17 28, 1950

6) Ipata, P. L.; G. Cercigni \& E. Balestreri: Partial purification and properties of cytidine deaminase from baker's yeast. Biochemistry 9: 3390 3395, 1970

7) Lowry, O. H.; N. J. Rosbrough, A. L. FarR \& R. J. Randall: Protein measurement with the Folin phenol reagent. J. Biol. Chem. 193: 265 275, 1951

8) Davis, B. J.: Disc electrophoresis. II. Method and application to human serum proteins. Ann. New York Acad. Sci. 121: 404 413, 1964

9) Archibald, W. J.: A demonstration of some new methods of determining molecular weights from the data of ultracentrifuge. J. Phys. Chem. 51: 1204 1214, 1947

10) Weber, K. \& M. Osborn: The reliability of molecular weight determinations by dodecyl sulfatepolyacrylamide gel electrophoresis. J. Biol. Chem. 244: 4406 4412, 1969

11) Vesterberg, O. \& H. Svensson: Isoelectric fractionation, analysis, and characterization of ampholites in neutral $\mathrm{pH}$ gradients. IV. Further studies on the resolving power in connection with separation of myoglobins. Acta Chem. Scand. 20: 820 834, 1966

12) Williams, D. E. \& R. A. Reisfeld: Disk electrophoresis in polyacrylamide gels. Extension to new conditions and buffer. Ann. New York Acad. Sci. 121: 373 381, 1964

13) Reisfeld, R. A.; U. J. Lewis \& D. E. Williams: Disk electrophoresis in polyacrylamide gels. Nature 195: 281, 1962

14) Pollock, M.R.: The activity and specificity of inducers of penicillinase production in Bacillus cereus, strain NRRL 569. Biochem. J. 66: 419 428, 1957

15) Ismande, J.; F. D. Gillin, R. J. Tanis \& A. G. Atherly: Properties of penicillinase from Bacillus cereus 569. J. Biol. Chem. 245: 2205 2212, 1970

16) Окамото, S. \& Y. SuzuKi: Chroramphenicol-, dihydrostreptomycin-, and kanamycin-inactivating enzymes from multiple drug-resistant Escherichia coli carrying episome R. Nature 208: 1301 1303, 1965

17) J 3: $318 \sim 356,1961$

18) ANDRews, P: The gel-filtration behaviour of proteins related to their molecular weights over a wide range. Biochem. J. 96: 595 606, 1965 